\title{
THE DEVELOPMENT OF THE LAND MARKET AND ITS IMPACT ON LAND MANAGEMENT EDUCATION IN RUSSIA IN THE SECOND HALF OF THE XIX CENTURY
}

\author{
Victoria Gromova \\ Postgraduate, Belgorod National Research University, 85 Pobeda Street, Belgorod, Russia, \\ E-mail: gromvv@mail.ru
}

\begin{abstract}
The purpose of this article is to study the land market and land management education, to establish the relationship of their development. With the abolition of serfdom, the redistribution of private land property began. The land holdings of the nobles began to become the property of other estates. The land turned into a commodity, the land market developed. This led to an aggravation of the problems of land ownership and land use. A number of them were related to surveying, determining the composition and value of land. There were not enough specialists in these areas and measures were taken to train them. Thus, the development of the land market contributed to the development of land management education. The article considers the stages of development and levels of land management education. The land market was studied on the example of the Central Industrial Region of European Russia. In this area, the estates of the main sellers and buyers, the number of transactions, the volume of trade turnover, the value of land are determined. The analysis of these indicators made it possible to identify the processes of redistribution of private land ownership.
\end{abstract}

Keywords: education, land management, land surveying, school, university, land market, reform.

\section{INTRODUCTION}

The liberation of the peasants from serfdom radically changed the conditions of farming in the Russian countryside [Strebut, 1889]. The issue of the need to train qualified specialists in the agricultural sector has become one of the key ones. Agronomists, field growers, cattlemen and other specialists were required. Before the reform of 1861, the redistribution of the land fund took place within the nobility, as the main private landowner. With the abolition of serfdom, it became possible for the transfer of landholdings to the ownership of other estates through purchase and sale. The land market began to develop. At the same time, the presence of a large number of non-demarcated lands, striped and multi-lane was one of the serious obstacles to its development.

The need to clarify the boundaries, composition and value of land, their landowners and land users contributed to the development of land surveying and land surveying education, which has become one of the topical areas of agrarian education.

In the second half of the XIX-th century, the problem of the redistribution of land ownership did not find its solution, became one of the main reasons for the October Revolution of 1917 and has not lost its significance at the present time. 
To date, there are very few research works on the study of the processes that took place in the land market of the Russian Empire in the 60s-90s of the XIX century. Therefore, the study of the historical aspects of the development of the land market will make it possible to better understand the processes that took place in the Russian countryside during the post-reform period. The study of the issues of redistribution of private land property, in the context of the development of land management education, is one of the areas of research on this issue.

\section{METHODOLOGY}

The methodological basis of the research is formed by dialectics and classical methods of writing historical research - the principles of historicism, scientific objectivity and consistency. These methods make it possible to study phenomena and processes in their development. Empirical methods: analysis of literature, method of comparison and grouping, interpretation made it possible to determine the processes of formation of education in the field of land management.

Using the statistical method, the general laws of the development of the land market were revealed, the estate composition of the main sellers and buyers was determined, the processes of integration of the noble, merchant, peasant and bourgeois estates into the land trade were studied. The historical and typological method made it possible: first, to study the processes of redistribution of private land property in the context of the development of agrarian education; secondly, to identify the processes taking place in the land market.

The comparative-historical method made it possible to identify the features of the development of regional land markets, to compare with the general trends that existed in the land market of European Russia. The use of an interdisciplinary approach at the junction of agrarian history and statistics made it possible to determine the influence of economic and social factors on the redistribution of private land ownership. The systematic approach method made it possible to establish the relationship between various data and present them in the form of an integrated study.

\section{RESULTS}

The land tenure of personal owners was characterized by great mobility, which grew over time [Kosinsky, 1918].

The nobility, being the largest seller in the land market, was at the same time the largest buyer, acquiring more land than other estates. In general, in European Russia, the percentage of participation of nobles in land purchases in 1863-1872 was 51.6\%, in 1873-1882 - 42.9\%, in 1883-1892 - 34.7\% and in 1893-1897 $33.2 \%$. Despite the fact that their share was constantly decreasing, and by 1898 the first place in these operations had passed to the peasants, until the end of the 19th century more than half of the land sold by the nobles remained in the hands of this class [Korelin, 1879].

Consider the development of the land market and the redistribution of private property on the example of the Central Industrial Region (CPR) of European Russia. This area was one of the most densely populated in Russia and the problems of redistribution of land property were especially pronounced in it. Noblemen, peasants, merchants and burghers were the main sellers and buyers of land, since these estates made the largest number of purchase and sale transactions in the land market.

From 1863-1892, the nobles of the CPR made 55,794 transactions for the sale of land and 17,369 transactions for its purchase. The volume of land sold and bought by the nobles was significantly higher than that of other estates. The nobles sold 10,018 thousand dess., Of which 4,510 thousand dess. or $45 \%$ of the land sold, they bought it back. [Rainbot, 1901].

As a result of the transactions, the noble land tenure decreased by 5,508 thousand dess., Which amounted to $55 \%$ of the land put up for sale by the nobles. The specified amount of land passed into the ownership of other estates [Rainbot, 1901].

From the sale of land, the nobles rescued 182,422 thousand rubles. of which - 77945 thousand rubles. was spent again to buy it. Thus, the net income received by the nobles from operations in the land market amounted to 104,477 thousand rubles. ... [Rainboat, 1901]

In relative terms, the nobles made $49 \%$ of transactions for the sale of land and $15 \%$ of transactions for its purchase. This estate accounted for $73 \%$ of the sold and $33 \%$ of the purchased land. As a result of the sale of land, $66 \%$ of the capital of the land market was transferred to them, of which $43 \%$ was again directed to the purchase of land [Rainbot, 1901].

The peasants made 27,091 transactions for the sale of land and 40,130 transactions for its purchase, which 
amounted to $24 \%$ and $35 \%$, respectively, of the total number of transactions made in the region's land market. The peasants were in first place in terms of the number of transactions and purchases, in second (after the nobles) - in terms of the number of transactions and sales. The market turnover of peasant lands was insignificant. The peasants bought 1463 thousand dess., Sold - 605 thousand dess., This was respectively $11 \%$ and $4 \%$ of the total amount of land sold and purchased. Out of 1463 thousand dess. purchased land - 605 thousand dess. or $41 \%$ of the peasants sold again. For the purchase of land, the peasants spent 28951 thousand rubles, of which 12618 thousand or $44 \%$ they returned through the sale of land. From the sale of land, the peasants received $5 \%$ of the capital of the land market, and spent $11 \%$ on the purchase of land. As a result of participation in trade relations in the land market, the land tenure of peasants increased by 858 thousand dess., The purchase of which was spent 16333 thousand rubles. [Rainbot, 1901].

The purchased land was concentrated mainly in the hands of the well-to-do peasantry. [Lenin, 1899].

During the period from 1863 to 1892, merchants made 11,228 transactions for the purchase of land and 6,355 transactions for the sale of land, which respectively accounted for $10 \%$ and $6 \%$ of the total number of transactions in the land market. As a result of the transactions made, merchants sold 1,189 thousand dess., Purchased 3,052 thousand dess. or, respectively, 9\% and 22\% of the land in turnover. Merchants sold $39 \%$ of the purchased land [Rainbot, 1901].

Other estates participating in trade relations in the land market made $10 \%$ of transactions for the purchase of land and $10 \%$ of transactions for its sale of the total number of transactions. The share of other estates accounted for $10 \%$ of the purchased and $18 \%$ of the sold land in circulation. $24 \%$ of the capital of the land market was spent on the purchase of land, and 16\% was received from its sale [Rainbot, 1901].

These processes of mobilization of land ownership entailed a number of land management works. There was a shortage of specialists with specialized knowledge and qualifications in this area. There is a need to open new educational institutions in this profile. A number of land surveying schools were opened before the 1861 reform. In 1779, at the Land Survey Office in Moscow, the first special land survey educational institution in Russia was created - the Konstantinovskaya Land Survey School. In 1819 it was renamed into the Constantine Land Survey (Land Survey) School, in 1835 - into the Imperial Constantine Land Survey Institute (KMI). Currently, it is the Moscow State University for Land Management.

In 1822, the Corps of Military Topographers was organized under the leadership of the Military Topographic Depot for centralized cartographic surveys on the territory of the Russian Empire.

In 1832, a school of land surveyors was organized at the Forestry Institute. In 1835, a school of draftsmen was organized at the land survey office, which served as the basis for the formation of the Corps of Civil Topographers (KGT). KGT was officially established under the Ministry of State Property in 1838. It functioned until 1873, then it was abolished (connected with the Konstantinovsky Land Survey Institute). The purpose of the establishment of the KGT was "for the production of land surveying and assessment of state lands and lands." The KGT consisted of: 1) companies of civil topographers, formed from graduates of the Land Survey and Forestry Institutes, as well as from land surveyors and volunteers in the service; 2) drawing room; 3) a mechanical institution for the manufacture of geodetic instruments [Teterin, 2007]. In 1843, additional classes of elementary land surveying were established in 15 provinces of Russia at the district schools. The Maryinsky Orphanage in St. Petersburg, which raised the children of the nobility, was transformed into the Maryinskoye Land Survey School [Ryazanov, 2009].

In the process of preparing the reform of 1861, government circles were aware of the impending need for specialists in land management. General surveying work in Russia has caused an obvious shortage of land surveyors.

In 1858, the number of students at the Konstantinovsky Survey Institute increased to 260 people, and the school of draftsmen, renamed the School of Survey Surveyors, then numbered 240 students.

In 1859, according to the "Highest approved, all-subject" report of the Minister of State Property, Count Muravyov, two-year land surveying and taxation classes were founded at the Konstantinovsky boundary and Gorigoretsky agricultural institutes. In these classes, specialists were trained for the production of surveys and taxation of land property. Boys of all classes were allowed to study in these classes from the age of 16. In the years 1860-1861, additional classes were opened at the gymnasiums in 38 provinces, where about 900 people studied. The land surveyors of the Land Survey Department were instructed to teach the boys from the landlord peasants simple land surveying [Volkov, 2000].

In the 1870 s, due to the need to train land surveyors, the first 4 land survey schools were opened: Pskov, 
Penza, Kursk, Orenburg. In 1889, a land surveying school was opened in Tiflis. In 1895, 294 students graduated from all five schools. Those who graduated from the course were successfully assigned to the service with the 14th grade or received only the title of private land surveyors. By 1916, there were fifteen land surveying schools with 2,093 students [Volkov, 2000].

In 1908, special courses were organized in the KMI and land management schools: 300 people studied at the KMI, 100 people each, and at 26 provincial drafting schools - 50 people each. A total of about 2000 people. [Teterin, 2007].

Thus, in the second half of the XIX-th century, land management education in Russia developed rapidly. The number of educational institutions grew, the areas of training and forms of education expanded. Education became multilevel and accessible to all. At the beginning of the 20th century, these processes continued.

In the second half of the XIX-th century, the redistribution of private land ownership between estates began, and the land market began to develop. This led to the emergence of a need for qualified personnel in the field of land management and an increase in the number of educational institutions specializing in this area.

The analysis of literature and statistical sources, carried out in this article, allows us to draw the following conclusions:

1. With the beginning of the reforms to abolish serfdom, conditions appeared for the free transfer of land from the nobility to the ownership of other estates. The private land ownership market began to develop;

2. From the nobility, land tenure was transferred mainly to merchants, peasants and bourgeois, since they made more transactions for the purchase of land and bought land in a larger volume than the rest of the estates (excluding the nobles).

3. Peasants completed most of the land purchase transactions, but the amount of land purchased was relatively small. Merchants were in second place after the nobles in terms of the volume of purchased land. The bourgeoisie made more transactions for the sale of land than the merchants. The volumes of land sold and bought by the bourgeoisie were insignificant relative to the other above-mentioned estates.

4. Problems of land management held back the mobilization of private land ownership;

5. There was a need for specialists with special knowledge in the field of land management, and measures were taken at the state level to train them.

\section{CONCLUSION}

The right to use, own and dispose of land is one of the key points in the development of the economic, social and cultural development of the state. Land tenure problems have existed since ancient times and have not lost their relevance at the present time. Land as a commodity is one of the main components of the agrarian market, on the degree of development of which in the 19th century the national welfare of Russia depended. The conditions for the emergence and development of the land market arose with the beginning of reforms to abolish serfdom, since class restrictions for the free transfer of land from the nobles to the ownership of other classes began to be gradually removed.

The nobles were the main sellers of land in the market. The number of land sales transactions made by them, as well as the volumes of land sold and purchased, were significantly higher than that of other estates. In terms of the number of transactions for the purchase of land, the nobles were in second place after the peasants, which does not diminish the role of the nobility as a key participant in the land market that determines its development.

The peasants completed most of the land purchase transactions, but the amount of land purchased was relatively small. The merchants were in second place after the nobles in terms of the volume of purchased land, although they bought three times less. The bourgeoisie made more transactions for the sale of land than the merchants. The volumes of land sold and bought by the bourgeoisie were insignificant relative to the other above-mentioned estates.

Despite the difference in the number of transactions and the volumes of purchased and sold land, these estates had the greatest impact on the formation of the land market.

The development of the land market from 1863 to 1892 had a significant impact on the cross-class redistribution of private land property. At the same time, by the end of the 19th century, most of the private land continued to belong to the nobles, they were the main participants in the land market in the post-reform period and contributed elimination of the reasons hindering the development of the land market. 
One of such significant reasons was the problem of land management and land use. This required special measures at the state level aimed at the development of land management education. Educational institutions of different levels were opened. Education became all-class. At the end of the XIX-th and the beginning of the XX-th centuries, the mobilization of agricultural land led to a sharp development of land management in the agrarian education of Russia.

\section{REFERENCE LIST}

Ershov B.A. (2010) The Russian Orthodox Church and secular power in the Voronezh province in the XIX early XX centuries. GOU VPO "Voronezh State Technical University". Voronezh. 167 p. (in Russ).

Ershov B.A. (2010) The system of spiritual education in Voronezh province in the 19th century. Education and Society. №. 5 (64). Pp. 105-108. (in Russ).

Ershov B.A., Fursov V.N. (2018) The Russian Church in the State Mechanism of Russia. Bulletin SocialEconomic and Humanitarian Research. № 1. Pp. 32-37. (in Engl).

Ershov B.A., Perevozchikova L.S., Romanova E.V. (2019) Globalization and Intensification of Spiritual Values in Russia in the Philosophical Aspect. 6th International Conference on Education and Social Sciences Abstracts \& Proceedings. Pp. 208-212. (in Engl).

Ershov B.A., Perevozchikova L.S., Romanova E.V., Ashmarov I.A. (2019) The Concept of Spirituality in Social Philosophy. Smart Innovation, Systems and Technologies. T. 139. Pp. 688-694. (in Engl).

Romanova E.V., Perevozchikova L.S., Ershov B.A. (2017) The Lifestyle of the Human Being in the Information Society. 3rd International Conference on Advances in Education and Social Sciences Proceedings of ADVED Pp. 950-954. (in Engl).

Anfimov A. M. (1969) Large landowner economy of European Russia (late XIX-early XX century). USSR Academy of Sciences. Institute of the History of the USSR. Moscow. Nauka. 394 p. (in Russ).

Milestones of Russian land management. (2000) Time, events, people. State. com.Ros. Federation on land. politics. State University for Land Management. Moscow: GUZ. 223 p. (in Russ).

Druzhinin N. M. (1978) The Russian village at the turning point 1861-1880. Moscow. Nauka. 136 p. (in Russ).

History of land relations and land management: textbook (2009). Voronezh: FGOU VPO Voronezh State University. 183 p. (in Russ).

Kovalchenko I. D., Milov L. V. (1974) All-Russian agricultural market, XVIII-early XX century. Experience in quantitative analysis. Moscow. Nauka. 399 p. (in Russ).

Kosinsky V. A. (1918) On the agrarian question. Issue 2. Part 2. The main trends in the mobilization of land ownership and their socio-economic factors. Kiev. P. 14. (in Russ).

Korelin A. P. (1979) The nobility in post-reform Russia. 1861-1904. Composition, number, corporate organization. Moscow. Pp. 55-57. (in Russ).

Litvak B. G. (1991) The Russian village in the reform of 1861. Chernozem center. 1861-1895. Moscow. Publishing House of political literature. 93 p. (in Russ).

Lenin V. The development of capitalism in Russia. PSS. Fifth edition Vol. 3. 112 p. (in Russ).

Lituev V. N. (1997) Land ownership as a noble monopoly in capitalist Russia. Moscow. Kalita. 148 p. (in Russ).

Lyashchenko P. I. (1901) Essays on agrarian evolution. St. Petersburg. 446 p.

Materials on the statistics of the movement of land ownership in Russia. (1901) Issue IV: A set of data on the purchase and sale of land in 45 provinces of European Russia for the thirty years from 1863 to 1892. Edited by A. E. Reinbot. SPb. Type. Kirshbaum. Pp. 14-25. (in Russ).

Materials on the statistics of the movement of land ownership in Russia. (1907) Issue XIII.: Pogubernsky results of land mobilization and average land prices for the 40th anniversary. 1863-1902. Edited by A. 
E. Reinbot. St. Petersburg, Type. Kirschbaum. (in Russ).

Materials of the editorial commissions on peasant affairs. (1860) St. Petersburg. Vol. 1. 1027 p. (in Russ).

Ostrovsky A.V. (2013) Grain production in European Russia at the end of the XIX-beginning of the XX century. St. Petersburg. 418 p. (in Russ).

Proskuryakova N. A. (1973) The location and structure of the noble land ownership of European Russia in the late XIX-early XX centuries. History of the USSR. № 1. Pp. 55-75. (in Russ).

RGADA F. 1273, Op. 1. Ch. 3, D. 2592 I. 46 p. (in Russ).

Teterin G. N. (2007) History of surveying, land management and land cadastre: monograph. Novosibirsk: SGGA. Pp. 60-63. (in Russ).

Stebut I. A. (1889) Agricultural knowledge and agricultural education: a collection of articles. 2nd ed. add. M.: I. I. Rodzevich's Printing house. Pp. 1-12. (in Russ). 